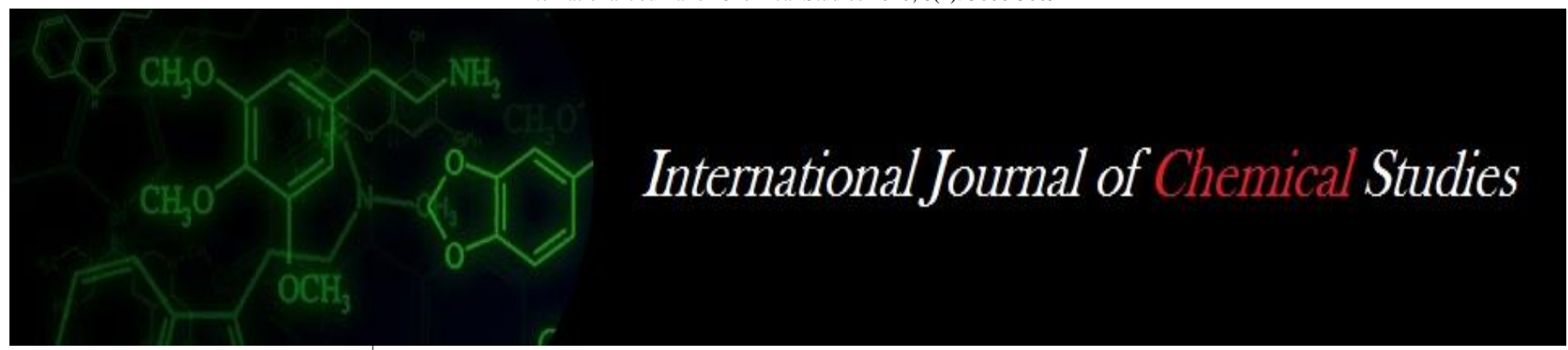

P-ISSN: 2349-8528

E-ISSN: 2321-4902

www.chemijournal.com

IJCS 2020; 8(2): 3006-3009

(C) 2020 IJCS

Received: 15-01-2020

Accepted: 19-02-2020

Banshi Lal Bhateshwar

M.Sc. Scholar, Department of Agronomy, Maharana Pratap University of Agriculture and Technology, Udaipur, Rajasthan, India

\section{SK Intodia}

Professor, Department of Agronomy, Maharana Pratap University of Agriculture and Technology, Udaipur,

Rajasthan, India

Kamal Garg

Division of Agronomy, IARI

New Delhi, India

\section{Piyush Choudhary}

Ph D Scholar, Department of Agronomy, Maharana Pratap University of Agriculture and Technology, Udaipur,

Rajasthan, India

\section{Ramniwas}

Ph D Scholar, Department of Agronomy, SKRAU, Bikaner, Rajasthan, India
Corresponding Author: Banshi Lal Bhateshwar M.Sc. Scholar, Department of Agronomy, Maharana Pratap University of Agriculture and Technology, Udaipur, Rajasthan, India

\section{Effect of FYM, mulching and agro-chemicals on growth parameters of wheat (Triticum aestivum L.) crop under different sowing dates}

\author{
Banshi Lal Bhateshwar, SK Intodia, Kamal Garg, Piyush Choudhary and \\ Ramniwas
}

DOI: https://doi.org/10.22271/chemi.2020.v8.i2at.9209

\begin{abstract}
A field experiment was conducted at was conducted at Instructional Farm, Rajasthan College of Agriculture, Udaipur during rabi 2016-17 to study the effect of FYM, mulching and agro-chemicals on growth of wheat (Triticum aestivum L.) crop under different sowing dates. The experiment consisted of 12 treatment combinations comprising of two sowing dates (Timely, Late) and six management practices, viz., control, FYM, Mulching, FYM + Mulching, FYM + Mulching + $\mathrm{ZnSO}_{4}$ and FYM + Mulching + $\mathrm{KCl}\left(\mathrm{P}_{0}, \mathrm{P}_{1}, \mathrm{P}_{2}, \mathrm{P}_{3}, \mathrm{P}_{4}, \mathrm{P}_{5}\right)$. The experiment was conducted in factorial randomized block design and replicated thrice. Results showed that timely sowing of crop had significant effect on various growth parameters i.e., plant height, dry matter accumulation, CGR, RGR and total number of tillers. Timely sown crop recorded significantly higher growth parameters which was found statistically superior over late sown crop treatment. Result further showed that $10 \mathrm{t} \mathrm{ha}^{-1} \mathrm{FYM}+4.0 \mathrm{tha}^{-1}$ Mulch $+0.2 \% \mathrm{KCl}\left(\mathrm{P}_{5}\right)$ recorded highest growth parameters followed by $10 \mathrm{t} \mathrm{ha}^{-1} \mathrm{FYM}+4.0 \mathrm{t} \mathrm{ha}^{-1} \mathrm{Mulch}+0.5 \% \mathrm{ZnSO}_{4}\left(\mathrm{P}_{4}\right)$ and $10 \mathrm{tha}^{-1} \mathrm{FYM}+4.0 \mathrm{tha}^{-1}$ Mulch $\left(\mathrm{P}_{3}\right)$.
\end{abstract}

Keywords: Agro-chemicals, FYM, Growth parameters, mulching and sowing date

\section{Introduction}

Wheat (Triticum aestivum L.) is the most widely cultivated food crop. It is most important cereal crop in terms of production and area in the world. It is the second most important staple food crop of our country. This crop was mainly responsible for the green revolution and mitigating the problem of food insecurity in India. Wheat is cultivated in almost all countries. The major wheat producing countries are China, India, USA, Russia, Canada and Australia. It is the only cultivated species in its genus and belongs to grass family Poaceae (Gramineae). It is also known as "King of Cereal". Wheat compares well with other important cereals in its nutritive value. It contains more protein than other cereals. Wheat has a relatively high content of niacin and thiamine. Wheat grain contains 11-12 per cent protein beside "gluten" which is very essential for bakers. It is cultivated in wide range of climatic environments and geographic region (Dixon et al., 2009) ${ }^{[9]}$. It is the main staple food of nearly 35 per cent of the world population. Globally wheat stands second in terms of total production with a quantum of 713.97 million tonnes from 220.45 million ha area (FAS/USDA, 2014). India has the largest area under wheat (31.2 million ha), with a productivity of $3075 \mathrm{~kg}$ ha-1 and is the second largest producer of wheat (95.9 million tonnes) after China in the world (FAOSTAT, 2017) ${ }^{[4]}$. In Rajasthan, the area and production of wheat was 3.3 million hectare and 12.43 million tonnes during 2016-17, respectively (Govt. of Rajasthan, 2016-17). Growth and development of wheat is adversely affected by environmental stresses like high temperature, soil moisture deficit, low light intensity, etc. (Joshi et al., 2007 and Modarresi et al., 2010) ${ }^{[7,10]}$. In last few years, temperature fluctuation (variation) during wheat growing season was also observed in Rajasthan and thereby, growth and yield of timely as well as late sown wheat was adversely affected. The impact of high temperature on wheat productivity can be minimized by adoption of various management practices. Adjustment in sowing time is the most important agronomic strategy to counteract the adverse effect of temperature stress. The optimum time of sowing for wheat crop in India is first fortnight of November. 
The delay in sowing of crop is mainly because of late harvest of paddy crop, delay in field operations, climate changes etc. which results in sowing of crop up to first fortnight of January (Kajla et al., 2015) ${ }^{[8]}$. A traditional agricultural practice of applying nutrients was through organic manures such as green manures, farmyard manure (FYM) etc. Organic matter like FYM not only provides available nutrients to the plants but also provide favourable soil environment and increase waterholding capacity of soil for longer time. Mulching has been proved useful in conserving moisture and increasing productivity in wheat. In recent past some encouraging results were obtained with foliar spray of agro-chemicals and various nutrients at post flowering stage on yield of wheat. The $\mathrm{KCl}$ foliar spray helps plant to maintain higher water potential as potassium plays important role in osmo-regulation and thereby it increases osmotic potential of leaves, which causes reduction in loss of water from leaves. Zinc is one of those micronutrients which have an important role in metabolic activities of the most plants. Hence, the present experiment was conducted to assess the effect of FYM, mulching and agro-chemicals on growth of wheat (Triticum aestivum L.) crop under different sowing dates.

\section{Materials and Methods}

The experiment was conducted during rabi season 2016-17 at Instructional Farm, Rajasthan College of Agriculture, Udaipur (Rajasthan). The soil of experimental site was clay loam in texture, having slight alkaline reaction ( $\mathrm{pH} 7.7)$. The soil was medium in available nitrogen $\left(295.3 \mathrm{~kg} \mathrm{ha}^{-1}\right)$ and phosphorus $\left(18.4 \mathrm{~kg} \mathrm{ha}^{-1}\right)$, and high in available potassium $\left(292.7 \mathrm{~kg} \mathrm{ha}^{-1}\right)$. The experiment comprised of twelve treatment combinations (two sowing dates and six management practices) that were laid out in factorial randomized block design and replicated three times. The plot size was $1.8 \mathrm{~m} \times 8.0 \mathrm{~m}$. The wheat variety HI-1544 was sown on 10 November, 2016 and 15 December, 2016 as per treatments. A uniform seed rate of 100 $\mathrm{kg} \mathrm{ha}^{-1}$ was used at inter row spacing of $20.0 \mathrm{~cm}$. In order to obtain uniform plant stand, seeds were weighed for each plot separately. Sowing was done manually in furrows followed by irrigation. Recommended dose of fertilizers, i.e., $90 \mathrm{~kg} \mathrm{~N}+$ $60 \mathrm{~kg} \mathrm{P}_{2} \mathrm{O}_{5} \mathrm{ha}^{-1}$ were applied through DAP and urea. Half of $\mathrm{N}$ and full dose of $\mathrm{P}$ were applied as a basal dose at the time of sowing. Remaining quantity of $\mathrm{N}$ were applied as top dressing on standing crop through urea in two equal split doses at the time of first and second irrigation. Well rotten FYM was applied @ $10.0 \mathrm{t} \mathrm{ha}^{-1}$ at the time of sowing as per treatments. Maize stover was applied as mulch @ $4.0 \mathrm{t} \mathrm{ha}^{-1}$ just after sowing of the crop as per treatments. Agrochemicals $\left(\mathrm{ZnSO}_{4}\right.$ and $\left.\mathrm{KCl}\right)$ were weighed as per treatments and dissolved in water (600 liter $\mathrm{ha}^{-1}$ ) and applied as per treatments. The agro- chemicals were sprayed through knapsack sprayer fitted with flat fan nozzle. Five plants were randomly selected from each plot and height of tagged plants was measured at 30, 60, 90 DAS and at harvest. The periodical change in dry matter accumulation at successive growth stages, i.e., 30, 60, 90 DAS and at harvest was recorded. Plant samples were harvested from a row length of $1.0 \mathrm{~m}$ in the second row on either side in each plot. These samples were sun dried for 2-3 days and then oven dried at 65 ${ }^{\circ} \mathrm{C}$ temperature till constant weight was attained. After drying, the samples were weighed for computing the dry weight (g) of plants. Crop growth rate and relative growth rate was computed between 30-60 and 60-90 DAS by the following formulae as given by Redford (1967) ${ }^{[12]}$. Number of total tillers was manually counted on $1.0 \mathrm{~m}^{-1}$ row length at 45
DAS. Total numbers of tillers from four randomly selected 0.5 $\mathrm{m}$ area were counted in each plot and average number of tillers $1.0 \mathrm{~m}^{-1}$ was worked out. The crop was harvested on maturity. The plants from border area were harvested separately and removed from each plot. The plants from net area were harvested and produce was tied in bundles and tagged. Dried bundles of individual plot were weighed to record biological yield and then threshed with power operated thresher and the produce was winnowed, cleaned and weighed separately to record grain yield plot $^{-1}$ and to compute yield $\mathrm{kg}$ $\mathrm{ha}^{-1}$.

$$
\mathrm{CGR}=\frac{\mathrm{W}_{2}-\mathrm{W}_{1}}{\mathrm{t}_{2}-\mathrm{t}_{1}}\left(\mathrm{~g} / \mathrm{m}^{2} / \text { day }\right)
$$

Where,

$\mathrm{W}_{1}=$ Total crop dry matter $/ \mathrm{m}^{2}$ at time $\mathrm{t}_{1}$

$\mathrm{W}_{2}=$ Total crop dry matter $/ \mathrm{m}^{2}$ at time $\mathrm{t}_{2}$

$\mathrm{t}_{1}=$ Time at first observation

$\mathrm{t} 2=$ Time at second observation

$$
\operatorname{RGR}(\mathrm{mg} / \mathrm{g} / \text { day })=\frac{\log _{\mathrm{e}} \mathrm{W}_{2}-\log _{\mathrm{e}} \mathrm{W}_{1}}{\mathrm{t}_{2}-\mathrm{t}_{1}}
$$

Where,

$\mathrm{W}_{1}=$ Total crop dry matter at time $\mathrm{t}_{1}$

$\mathrm{W}_{2}=$ Total crop dry matter at time $\mathrm{t}_{2}$

$\mathrm{t}_{1}=$ Time at first observation

$\mathrm{t}_{2}=$ Time at second observation

$\log _{\mathrm{e}}=$ Natural $\log$

\section{Results and Discussion Effect on Growth parameters Sowing Date}

The data presented in (Table 1 and 2) show that different dates of sowing brought about significant variation on various growth parameters i.e., plant height, dry matter accumulation, CGR, RGR and total number of tillers. Higher plant height was recorded under timely sown crop over late sown crop at different growth stages of crop (Table 1). This might be attributed to more favorable environment available under timely $\left(10^{\text {th }}\right.$ November) sown crop in comparison to late $\left(15^{\text {th }}\right.$ December) sown crop. Plant height is mainly controlled by the genetic makeup of genotype, but it is also affected by environmental conditions. This was attributed due to maximum period available to timely sown crop in comparison to delayed sowing resulting in taller plant. Thus, the height of the plants was reduced by experiencing higher temperature in late sown crop. The findings of this investigation corroborate with those observed by Kumar and Sharma (2003) ${ }^{[9]}$, Shahzad et al. (2007) ${ }^{[13]}$ and Amrawat et al. (2014) ${ }^{[1]}$. A perusal of data (Table 1) show that dry matter accumulation (DMA) varied significantly during all growth stage under different sowing dates. Significantly more dry matter accumulation was recorded under timely sown crop $\left(\mathrm{D}_{1}\right)$ over late sown crop $\left(D_{2}\right)$. This was mainly because of production of more number of tillers $\mathrm{m}^{-1}$ row (Table 2) and the crop experienced favorable weather during crop growth period. The data (Table 2) reveal that different dates of sowing brought about significant variation in crop growth rate and relative growth rate between 30-60 DAS and 60-90 DAS. The data (Table 2) unveil that different dates of sowing brought about significant variation in number of tillers $\mathrm{m}^{-1}$ row length at 45 DAS. Number of 
tillers were significantly reduced under late sown crop $\left(D_{2}\right)$ by 11.03 per cent as compared to timely sown crop $\left(D_{1}\right)$ (108.63). The interesting behavior exhibited by different sowing dates may be explained by the fact that the timely sown crop was exposed to more favorable weather during the early stages of life cycle. The different growth and reproductive phases of plant life could be completed at appropriate timings, which are also visible in the various phenological stages under timely sown crop. The late sown crop could not enjoy the advantages of favorable weather conditions. Similar results were also reported by Kumar and Sharma (2003) ${ }^{[9]}$ and Dhaka et al. (2006) ${ }^{[3]}$ and they reported significant reduction in number of tillers with delayed sowing in wheat.

\section{FYM, Mulching and Agro-chemicals}

The data (Table 1 and 2) shows that application of FYM and mulch alone and in combination with agro-chemicals significantly influenced the growth parameters i.e., plant height, dry matter accumulation, CGR, RGR and total number of tillers. The results revealed that application of $10 \mathrm{t} \mathrm{ha}^{-1}$ $\mathrm{FYM}+4.0 \mathrm{t} \mathrm{ha}^{-1}$ mulch $+0.5 \% \mathrm{ZnSO}_{4}$ and $10 \mathrm{t} \mathrm{ha}^{-1} \mathrm{FYM}+$ $4.0 \mathrm{t} \mathrm{ha}^{-1}$ mulch $+0.2 \% \mathrm{KCl}$ significantly increased plant height at 60 DAS, 90 DAS and at harvest. This might be attributed to more congenial environment available under the influence of treatments (Table 1). Plant height is mainly controlled by the genetic makeup of genotype, but it is also affected by environmental conditions. In the present investigation, crop accumulated significantly higher dry matter in plants under the influence of treatments viz., $10 \mathrm{t} \mathrm{ha}$ ${ }^{1} \mathrm{FYM}+4.0 \mathrm{t} \mathrm{ha}^{-1}$ mulch, $10 \mathrm{t} \mathrm{ha}^{-1} \mathrm{FYM}+4.0 \mathrm{t} \mathrm{ha}^{-1}$ mulch + $0.5 \% \mathrm{ZnSO}_{4}$ and $10 \mathrm{t} \mathrm{ha}^{-1} \mathrm{FYM}+4.0 \mathrm{t} \mathrm{ha}^{-1}$ mulch $+0.2 \%$ $\mathrm{KCl}$ as compared to control at various growth stages (Table 1). This was mainly because of production of more number of tillers $\mathrm{m}^{-1}$ row length (Table 2). The data (Table 2) unveil that FYM and mulch alone and in combination with agrochemicals failed to record any significant effect on crop growth rate and relative growth rate (30-60 DAS and 60-90 DAS) over control. The results for number of tillers $\mathrm{m}^{-1}$ row indicates that application of $10 \mathrm{t} \mathrm{ha}^{-1} \mathrm{FYM}+4.0 \mathrm{t} \mathrm{ha}^{-1}$ mulch, $10 \mathrm{t} \mathrm{ha}^{-1} \mathrm{FYM}+4.0 \mathrm{t} \mathrm{ha}^{-1}$ mulch $+0.5 \% \mathrm{ZnSO}_{4}$ and $10 \mathrm{t} \mathrm{ha}^{-1}$ $\mathrm{FYM}+4.0 \mathrm{t} \mathrm{ha}^{-1}$ mulch $+0.2 \% \mathrm{KCl}$ registered higher number of tillers at 45 DAS and at the end of life process, i.e., at harvest (Table 2). The combined effect of FYM and mulch could be due to the favorite effect of adding FYM as a good source of plant nutrient. The superior performance of $10 \mathrm{t} \mathrm{ha}^{-1}$ $\mathrm{FYM}+4.0 \mathrm{t} \mathrm{ha}^{-1}$ mulch $+0.5 \% \mathrm{ZnSO}_{4}$ and $10 \mathrm{t} \mathrm{ha}^{-1} \mathrm{FYM}+$ $4.0 \mathrm{t} \mathrm{ha}^{-1}$ mulch $+0.2 \% \mathrm{KCl}$ may be attributed to integrated moisture-stress management practices involving application of FYM, which besides providing nutrition also increased water holding capacity, mulch helped in maintaining soil temperature, weed control and soil moisture content, foliar spray of $\mathrm{ZnSO}_{4}$ provided thermotolerance to the photosynthetic apparatus and spraying of $\mathrm{KCl}$ benefitted crop by osmoregulation and by increasing nutrient availability (Patil et al., 2014) ${ }^{[11]}$.

Table 1: Effect of FYM, mulching and agro-chemicals on plant height and dry matter accumulation of wheat

\begin{tabular}{|c|c|c|c|c|c|c|c|c|}
\hline Treatments & \multicolumn{3}{|c|}{ Plant height (cm) } & \multicolumn{3}{|c|}{ Dry matter accumulation (g/m row length) } \\
\hline & 30 DAS & 60 DAS & 90 DAS & At harvest & 30 DAS & 60 DAS & 90 DAS & At harvest \\
\hline Sowing date & & & & & & & & \\
\hline $\mathrm{D}_{1}$ & 21.83 & 47.00 & 92.06 & 99.06 & 29.33 & 138.00 & 199.72 & 228.94 \\
\hline $\mathrm{D}_{2}$ & 17.28 & 41.78 & 81.50 & 91.94 & 22.67 & 113.67 & 147.22 & 180.33 \\
\hline $\mathrm{SEm} \pm$ & 0.47 & 0.97 & 1.33 & 1.71 & 0.41 & 1.45 & 2.09 & 3.37 \\
\hline $\mathrm{CD}(\mathrm{P}=0.05)$ & 1.38 & 2.83 & 3.90 & 5.00 & 1.20 & 4.24 & 6.14 & 9.89 \\
\hline $\mathrm{P}_{0}$ & & & & & & & & \\
\hline $\mathrm{P}_{1}$ & 18.33 & 41.17 & 82.17 & 88.50 & 23.42 & 119.33 & 164.83 & 189.17 \\
\hline $\mathrm{P}_{2}$ & 18.67 & 42.67 & 84.33 & 92.67 & 24.08 & 125.33 & 170.00 & 192.50 \\
\hline $\mathrm{P}_{4}$ & 19.00 & 43.17 & 84.67 & 94.00 & 23.75 & 121.17 & 170.17 & 200.50 \\
\hline $\mathrm{P}_{5}$ & 20.50 & 44.33 & 86.83 & 95.83 & 28.17 & 129.33 & 177.83 & 208.00 \\
\hline $\mathrm{SEm} \pm$ & 20.33 & 46.17 & 89.33 & 98.67 & 28.33 & 130.33 & 178.17 & 212.67 \\
\hline $\mathrm{CD}(\mathrm{P}=0.05)$ & 20.50 & 48.83 & 93.33 & 103.33 & 28.25 & 129.50 & 179.83 & 225.00 \\
\hline
\end{tabular}

Note- NS- Non-significant, D1- Timely sowing (10 $0^{\text {th }}$ November, 2016), $\mathrm{D}_{2}$ - Late sowing $\left(15^{\text {th }}\right.$ December, 2016), $\mathrm{P}_{0}-\mathrm{Control}_{1} \mathrm{P}_{1}-10 \mathrm{t}$ ha ${ }^{-1} \mathrm{FYM}, \mathrm{P}_{2}-4 \mathrm{t}$ $\mathrm{ha}^{-1}$ Mulch, $\mathrm{P}_{3}-10 \mathrm{t} \mathrm{ha}^{-1} \mathrm{FYM}+4.0 \mathrm{t} \mathrm{ha}^{-1}$ Mulch, $\mathrm{P}_{4-} 10 \mathrm{tha}^{-1} \mathrm{FYM}+4.0 \mathrm{t} \mathrm{ha}^{-1} \mathrm{Mulch}+0.5 \% \mathrm{ZnSO}_{4}, \mathrm{P}_{5}-10 \mathrm{t} \mathrm{ha}^{-1} \mathrm{FYM}+4.0 \mathrm{t} \mathrm{ha}{ }^{-1} \mathrm{Mulch}+0.2 \% \mathrm{KCl}$.

Table 2: Effect of FYM, mulching and agro-chemicals on CGR, RGR and total number of tillers in wheat

\begin{tabular}{|c|c|c|c|c|c|}
\hline \multirow[t]{2}{*}{ Treatments } & \multicolumn{2}{|c|}{ CGR (g/m²/day) } & \multicolumn{2}{|c|}{ RGR (g/g/day) } & \multirow{2}{*}{$\begin{array}{c}\text { Total tillers (Numbers } \mathbf{~ m}^{-1} \text { row length) } \\
\text { At 45 DAS }\end{array}$} \\
\hline & $30-60$ DAS & $60-90$ DAS & $30-60$ DAS & $60-90$ DAS & \\
\hline \multicolumn{6}{|l|}{ Sowing date } \\
\hline $\mathrm{D}_{1}$ & 3.622 & 2.057 & 0.0517 & 0.0123 & 108.72 \\
\hline $\mathrm{D}_{2}$ & 3.033 & 1.119 & 0.0540 & 0.0086 & 96.65 \\
\hline SEm \pm & 0.051 & 0.090 & 0.0007 & 0.0006 & 1.44 \\
\hline $\mathrm{CD}(\mathrm{P}=0.05)$ & 0.149 & 0.264 & 0.0019 & 0.0017 & 4.23 \\
\hline \multicolumn{6}{|c|}{ FYM, mulching and agro-chemicals } \\
\hline $\mathrm{P}_{0}$ & 3.197 & 1.517 & 0.0545 & 0.0106 & 95.96 \\
\hline$P_{1}$ & 3.375 & 1.489 & 0.0554 & 0.0098 & 97.25 \\
\hline $\mathrm{P}_{2}$ & 3.247 & 1.633 & 0.0546 & 0.0112 & 98.18 \\
\hline $\mathrm{P}_{3}$ & 3.372 & 1.617 & 0.0508 & 0.0104 & 105.01 \\
\hline $\mathrm{P}_{4}$ & 3.400 & 1.594 & 0.0509 & 0.0102 & 108.63 \\
\hline $\mathrm{P}_{5}$ & 3.375 & 1.678 & 0.0508 & 0.0106 & 111.08 \\
\hline SEm \pm & 0.088 & 0.156 & 0.0011 & 0.0010 & 2.50 \\
\hline $\mathrm{CD}(\mathrm{P}=0.05)$ & NS & NS & 0.0033 & NS & 7.33 \\
\hline
\end{tabular}

Note- NS- Non-significant, $\mathrm{D}_{1}$ - Timely sowing $\left(10^{\text {th }}\right.$ November, 2016), $\mathrm{D}_{2^{-}}$Late sowing $\left(15^{\text {th }}\right.$ December, 2016), $\mathrm{P}_{0^{-}}$Control, $\mathrm{P}_{1^{-}}-10 \mathrm{t}$ ha ${ }^{-1} \mathrm{FYM}, \mathrm{P}_{2}-4 \mathrm{t}$ $\mathrm{ha}^{-1}$ Mulch, $\mathrm{P}_{3}-10 \mathrm{t} \mathrm{ha}^{-1} \mathrm{FYM}+4.0 \mathrm{t} \mathrm{ha}^{-1}$ Mulch, $\mathrm{P}_{4-} 10 \mathrm{tha}^{-1} \mathrm{FYM}+4.0 \mathrm{tha}^{-1} \mathrm{Mulch}+0.5 \% \mathrm{ZnSO}_{4}, \mathrm{P}_{5}-10 \mathrm{t} \mathrm{ha}^{-1} \mathrm{FYM}+4.0 \mathrm{t}$ ha ${ }^{-1} \mathrm{Mulch}+0.2 \% \mathrm{KCl}$. 


\section{Conclusion}

On the basis of the findings of the present investigation, it can be concluded that under prevailing climatic condition of agroclimatic zone IV A of the Rajasthan timely sown wheat crop and application of $10 \mathrm{t} \mathrm{ha}^{-1} \mathrm{FYM}+4.0 \mathrm{t} \mathrm{ha}^{-1}$ mulch $+0.2 \%$ $\mathrm{KCl}$ was found more superior treatment combination for obtaining higher growth parameters over rest of the treatment.

\section{Acknowledgements}

The authors are thankful to Head, Department of Agronomy, Rajasthan College of Agriculture, MPUA\&T Udaipur for providing field staff, facilities and assistance in conducting this research.

\section{References}

1. Amrawat, Taruna, Solanki NS, Sharma SK, Sumeriya HK. Analysis of wheat (Triticum aestivum L.) cultivars under different sowing dates and nitrogen levels. Annal of Biology. 2014; 30(2):253-256.

2. Dixon JH, Barun J, Kosina P, Crouch J. (eds.) Wheat facts and future. Mexico, D.F.: CIMMYT, 2009.

3. Dhaka AK, Bangarwa AS, Pannu RK, Malik RK, Garg R. Phenological development, yield and yield attributes of different wheat genotype as influenced by sowing time and irrigation levels. Agricultural Science Digest. 2006; 26(3):174-177.

4. Faostat. FAO Statistical Year book World Food and Agriculture, 2017.

http://www.fao.org/economic/ess/esspublications/essyear book/en/\#.U68A8v m SziU/

5. FAS/USDA. Foreign Agricultural Service/United States Department of Agriculture. Production, Supply and Distribution Online. http://apps.fas.usda. gov/psdonline/psdHome. Aspx, 2014.

6. Govt. of Rajasthan. Rajasthan Agricultural Statistics at a Glance. Directorate of Agriculture, Rajasthan, Jaipur, 2016-17, 60

7. Joshi AK, Mishra B, Chatrath R, Ferrara GO, Singh RP. Wheat improvement in India. Present status. Emerging challenges and future prospects. Euphytica. 2007; 157(1):431-446.

8. Kajla M, Yadav VK, Chhokar RS, Sharma RK. Management practices to mitigate the impact of high temperature on wheat. Journal of Wheat Research. 2015; $7(1): 1-12$

9. Kumar R, Sharma SN. Effect of levels of nitrogen on wheat as influenced by date of sowing. Annals of Agricultural Research. 2003; 24:104-110.

10. Modarresi M, Mohammdi V, Zali A, Mardi M. Response of wheat yield and yield related traits of high temperature. Cereal Research communication. 2010; 38(1):23-31.

11. Patil MD, Dhindwal AS, Rajanna GA. Integrated moisture stress management in wheat (Triticum aestivum L.). Indian Journal of Agronomy. 2014; 59(4):629-633.

12. Redford PJ. Growth analysis formulae: their use and abuse. Crop Science. 1967; 7:71-175.

13. Shahzad MA, Wasi-up-Din, Sahi ST, Khan MM, Ehsanullah, Ahmad M.Effect of sowing dates and seed treatment on grain yield and quality of wheat. Pakistan Journal of Agricultural Science. 2007; 44:581-583. 